\author{
Sergei BOSIAKOV ${ }^{1}$ \\ Anastasiya VINAKURAVA ${ }^{2}$ \\ Andrei DOSTA ${ }^{3}$
}

\title{
DEFORMATIONS AT THE CRANIOFACIAL COMPLEX DEPENDING ON THE HYRAX DEVICE DESIGN
}

\begin{abstract}
Finite element analysis of the stress-strain state of a human skull after the expansion of the maxilla with using different designs orthodontic appliance HYRAX was carried out. Finite element model of craniofacial complex and supporting teeth are obtained on the basis of tomographic data. An orthodontic appliance differs by the localization of the screw relative to the palate. The design with location of the rods and screw of device in the same horizontal plane as well as the design with the location of the screw at the $8 \mathrm{~mm}$ closer to the palate relative to the horizontal localization are considered. Deformations at the intact skull and a skull with a cleft palate were derived. The regions of the largest deformations of the skull bone structures are defined for different orthodontic device designs. Effect of the orthodontic device design on displacements of the supporting teeth is analyzed. The results can be used to design devices HYRAX for the orthodontic correction and treatment of the cross-bite patients.
\end{abstract}

Keywords: intact skull, palate cleft, HYRAX device, stress-strain state

\section{Introduction}

Cross-bite is the one of the anomalies of the mutual disposition of transversal dentition requiring active treatment. The most distributed cases of cross-bite are dysplasia of the jaw, chewing function decline or chewing on one side, a violation of the jaws, as well as congenital cleft palate. For the treatment of maxillary defects is used expansion of the upper jaw with large transversal forces. For this purpose, various orthodontic designs [3, 9, 10, 21] were used.

The maxillary expansion may be associated with a feeling of pressure to different areas of the maxilla, in particular under the eyes and near nasal cavity

\footnotetext{
${ }^{1}$ Autor do koresondencji/corresponding author: Sergei Bosiakov, Belarusian State University, 4 Nezavisimosti Avenue, 220030 Minsk, Belarus, tel.: (+375) 172095345, e-mail: bosiakov @bsu.by

2 Anastasiya Vinakurava, Rzeszow University of Technology, e-mail: vinakurava@prz.edu.pl

3 Andrei Dosta, Belarusian State Medical University, e-mail: dostastom75@mail.ru
} 
$[14,28]$. At the same time, an important element of the orthodontic treatment is to ensure maxillary extension without any side and negative effects [24].

A lot of finite element studies were carried out to assess the influence of the rapid maxillary expansion on the bone structures of the craniofacial complex and the supporting teeth in patients with and without cleft palate. Recent obtained results and the history of the development of this problem are described in [1, $11,12,15,16,19,20,25]$. Usually, in the works related to the calculation of the stress-strain state of the maxillary complex, the effect of orthodontic appliance is not modeled. The effect of the actual features of orthodontic device on the maxillary expansion was not investigated. The correct direction of forces and their distribution during maxillary expansion is still relevant. The aim of this study is finite element analysis of the bone deformations at the intact skull and skull with cleft palate after activation of the different designs of orthodontic device HYRAX.

\section{Materials and methods}

Stereolithography (STL) model of the skull was obtained with the use of MIMICS 14.12 (Materialise BV, Belgium) on the basis of 210 tomographic images of the dry cadaveric intact skull of adult man. Step of tomographic slices is $1 \mathrm{~mm}$. A similar approach was used in $[5,8,11,15]$ during development of three-dimensional solid model of the maxillary complex. The first and second premolars of the maxilla and the first permanent molars were removed in a process of generating STL-model. The finite element model is obtained after processing STL-model in 3-matic 6.1 MIMICS. The finite element model contains of 26445 nodes and 91731 elements like Solid72. Finite element discretization was performed automatically. Simulation of the periodontal ligament was not carried out, because it has little effect on the stress distribution in the bone structures of the craniofacial complex during maxillary expansion [27]. Maxillary sutures are also not taken into account in the finite element model, because the sutures in skull of an adult human the partially or fully ossified and have a small thickness [1].

Solid models premolars and first molars were obtained on the basis of tomographic data of the human skull in SolidWorks 2010 (SolidWorks Corporation, USA). The SolidWorks graphics primitives were used for modeling orthodontic device HYRAX. Crowns were installed on the first premolars and molars. The rods were attached to plates which can be moved apart in a horizontal plane by rotation of the screw. The length and width of the plates are $10 \mathrm{~mm}$ and $4 \mathrm{~mm}$ respectively. The radius of the rod cross-section is equal to $1 \mathrm{~mm}$, thickness is $0.2 \mathrm{~mm}$. Finite element models of the orthodontic device, premolars and molars are derived by use Mechanical Model ANSYS Workbench 13. Total number of elements is 13320 and total number of nodes is 26375 . The maximum size of the element of orthodontic device model is $1 \mathrm{~mm}$. Contacts between the crowns 
of orthodontic device and teeth, as well as skull and the teeth was assigned via contact elements CONTA173, CONTA174 and TARGE170 (without sliding and penetration). The boundary conditions for the skull correspond to rigid fixing of the foramen magnum nodes $[11,16,20]$. Finite element model of maxillary complex orthodontic appliances and boundary conditions are shown in fig. 1. Displacement of each plate along $x$-axis is $u=0.4 \mathrm{~mm}$ (corresponding to the activation of half-turned screws) $[3,6,18,22,26]$. The elastic properties of the tissues of the skull and dental orthodontic device material are indicated in tab. 1 .

a)

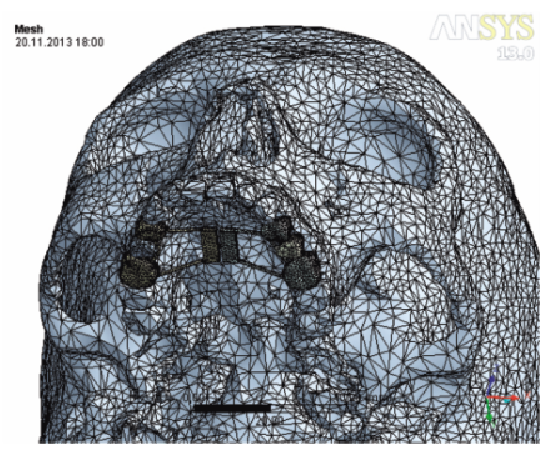

b)

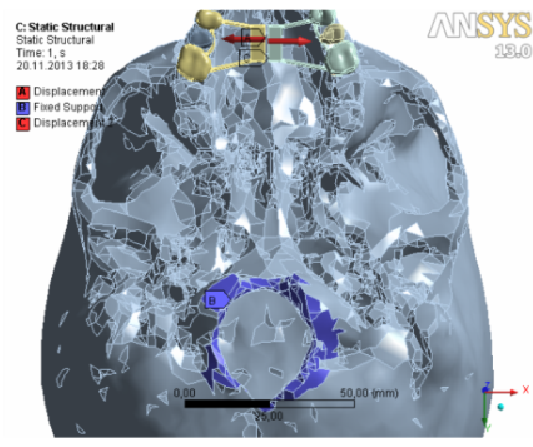

Fig. 1. Finite-element model of craniofacial complex with orthodontic device (a) and boundary conditions for FE model (b)

Table 1. Elastic properties of materials

\begin{tabular}{|l|c|c|}
\hline \multicolumn{1}{|c|}{ Materials } & Elasticity modulus, GPa & Poisson's ratio \\
\hline Orthodontic device & 200.0 & 0.3 \\
\hline Compact bone [23] & 13.7 & 0.3 \\
\hline Trabecular bone [23] & 8.0 & 0.3 \\
\hline Teeth [23] & 20.7 & 0.3 \\
\hline
\end{tabular}

Stress-strain states of the intact skull and skull with palate cleft were derived for two designs of orthodontic device. At the first design of orthodontic device the screw and rods are disposed in the same horizontal plane (model $A$ ). In the second design the screw was located on $8 \mathrm{~mm}$ closer to the palate with respect to the above horizontal plane (model $B$ ). The rods length for the models $A$ and $B$ changes from $8.15 \mathrm{~mm}$ to $12.20 \mathrm{~mm}$ and from 11.05 to $16.45 \mathrm{~mm}$, respectively. 


\section{Results and discussion}

Deformations of the intact craniofacial complex without cleft palate (fig. 2.) shows that the direction of displacement changes significantly with the movement of screw of orthodontic device to the palate. For model $A$ the deformations has a positive direction along the $z$-axis. For model $B$ the total deformations (including the $z$-axis components) directed along the negative direction of this axis. Skull in this case is rotated forward and downward. This fact is consistent with the results of research [17].

a)

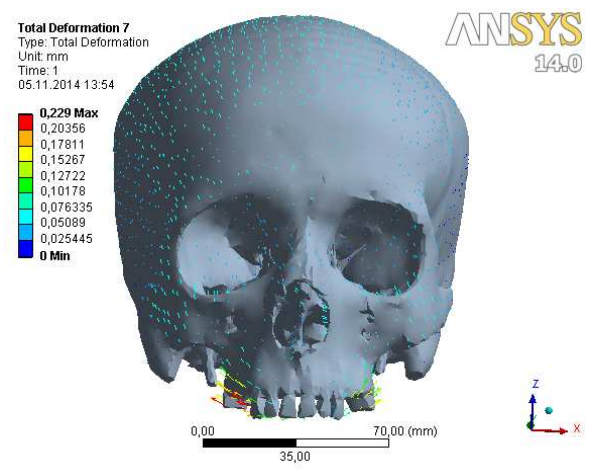

b)

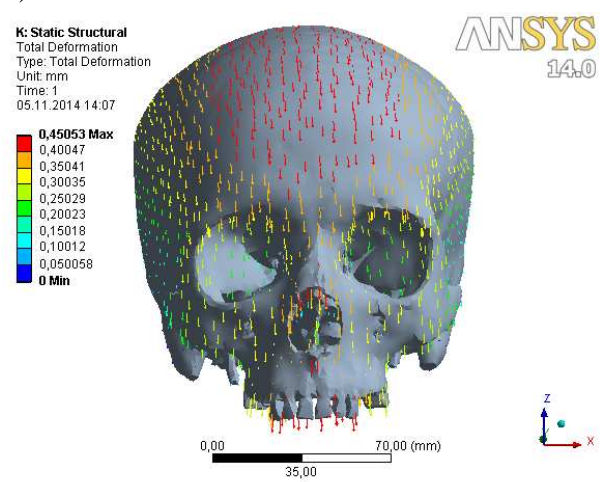

Fig. 2. Total deformations of intact skull (frontal view): a) $\operatorname{model} A, \mathrm{~b}) \operatorname{model} B$

The highest and lowest displacements of the maxillary bone structures along the coordinate axes are given in tab. 2. - it can be seen that the design of the device significantly affects the displacements in the bones of the skull. Transversal deformations of the maxilla decreased more than 2 times on the left side of the skull and more than 6 times on the right side for model $B$ in comparison model $A$. Largest deformations for the maxilla left side are $0.37 u$ (fig. 2a) and $0.12 u$ (fig. 2b), and for right side are $0.55 u$ (fig. 2a) and $0.08 u$ (fig. 2b). Some bone structures on the left side of the skull (the individual regions of the maxilla, zygomatic bone) displace to the right. This fact can be explained by the asymmetry of the craniofacial complex, as well as the asymmetrical fixing of crowns on the supporting teeth and rods on the crowns. For model $A$, maxilla near the front incisors slightly moves back along the $y$-axis in the sagittal plane. The greatest displacement in this direction is equal to $0.175 u$. The maxilla segment near molars and some other bones of the skull, including the zygomatic bone, move forward. In this direction the largest displacement is equal to $0.073 u$. Maxillary segment near front incisors and nasal cavity slightly move down (along the $z$-axis), the other bone structures of the skull are moved upwards. For model $B$, skull bone above the horizontal plane passing through the nasal crest 
moves forward; segment of the maxilla, located below of this plane moves backward. The anterior regions of the skull (maxilla, nasal, frontal and zygomatic bones) are moved down in the vertical direction; parietal and occipital region of the skull are rises. Thus, the skull is rotated in the sagittal plane and the center of rotation lies in the region of the nasal cavity. This corresponds to the results of experimental work [2] about determination of the skull center of resistance and the skull center of rotation during the maxillary expansion.

Table 2. Maximum and minimum displacements of the intact skull bone structures for models $A$ and $B$ of the orthodontic device

\begin{tabular}{|c|c|c|c|c|}
\hline \multirow{2}{*}{$\begin{array}{c}\text { Direction } \\
\text { of displace- } \\
\text { ments }\end{array}$} & \multicolumn{2}{|c|}{ Magnitude, mm } & \multicolumn{2}{|c|}{ The skull bone structures } \\
\hline & $\begin{array}{c}\text { model } \\
A\end{array}$ & $\begin{array}{c}\text { model } \\
B\end{array}$ & $\operatorname{model} A$ & $\operatorname{model} B$ \\
\hline \multirow[t]{2}{*}{ Along $x$-axis } & 0.107 & 0.047 & \multirow{2}{*}{\multicolumn{2}{|c|}{ Lateral parts of maxilla }} \\
\hline & -0.179 & -0.029 & & \\
\hline \multirow[t]{2}{*}{ Along $y$-axis } & 0.059 & 0.093 & $\begin{array}{l}\text { maxilla near first incisors, } \\
\text { frontal bone }\end{array}$ & maxilla \\
\hline & -0.029 & -0.431 & lateral part of the maxilla & frontal bone \\
\hline \multirow[t]{2}{*}{ Along $z$-axis } & 0.122 & 0.237 & lateral part of the maxilla & occipital bone \\
\hline & -0.059 & -0.443 & $\begin{array}{l}\text { maxilla near midpalatal } \\
\text { suture }\end{array}$ & $\begin{array}{l}\text { posterior part of the maxilla } \\
\text { and nasal bone }\end{array}$ \\
\hline
\end{tabular}

The behavior of supporting teeth during the maxillary expansion should be assessed. This caused by that increase in the size of the arc of the upper dentition is achieved in part by inclined rotational tooth movement. Incorrect installation of orthodontic device may be accompanied by dislocation of the supporting teeth and fenestration of cortical bone, root resorption and gingival recession [14]. At the same time, in the finite-element researches of the maxillary expansion the displacements of the supporting teeth are considered simultaneously with the displacements of the maxillary complex $[1,5,7,11,12,19,20,25]$. The displacement patterns of the supporting teeth are shown in fig. 3 .

Figure $3 \mathrm{a}$ shows that the movement direction of the maxilla and supporting teeth on the right side is the same. On the right side the first and second premolars are rotated. The centers of rotation of the tooth are located at the apex of the root. The center of rotation of the first and second premolar in a vertical plane parallel to the $x z$-plane islocated on $\approx 0.3 l$ and $\approx 0.27 l$ from the root apex respectively ( $l$ is the height of the corresponding tooth). Since displacements in the transverse direction are large enough (from $-0,150 \mathrm{~mm}$ in apical region till $0.356 \mathrm{~mm}$ for the points on the occlusal surface) in this plane dislocation of supporting teeth can occur.

In the vertical plane (parallel to $y z$-plane) all supporting teeth, except the first molar on the left side are rotated. The center of rotation lies in the body of 
the corresponding tooth. Tooth displacements in this plane are small (maximum displacement of apical region of supporting teeth on the right side is equal to $\approx 0.027 \mathrm{~mm}$ ). Taking into account the thickness of the periodontal ligament $(\approx 0.23 \mathrm{~mm}[20])$, it can be concluded that the displacements of teeth in the sagittal plane do not occur.

Figure $3 \mathrm{~b}$ shows that the displacements of the supporting teeth for model $B$ are directed mainly downwards, as well as displacement of all maxillary complex. The magnitudes of transversal displacements of teeth approximately coincide with the displacements of the alveolar region of the maxilla. Therefore, we can conclude that the centers of rotation of the abutment teeth and upper jaw halves are located in the nasal cavity.

a)

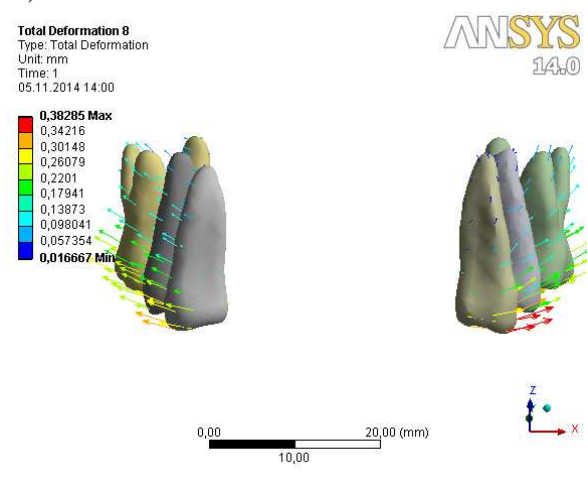

b)

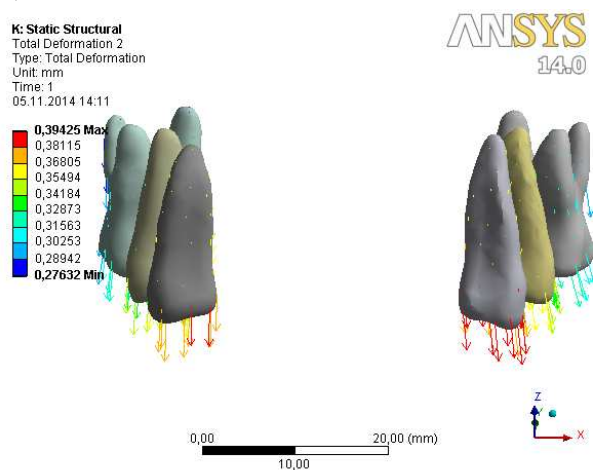

Fig. 3. Total deformations of supporting teeth in intact skull with orthodontic device (frontal view): a) model $A$, b) model $B$

Deformations of the maxillary complex with cleft for orthodontic device with two different structures are shown in fig. 4. The highest and lowest displacements along the coordinate axes of the maxillary bone structures of the complex with unilateral cleft palate are given in tab. 3 .

For the models $A$ (fig. 4a) and $B$ (fig. 4b) of orthodontic appliance the greatest transversal movement on the left side of maxilla are $0.96 u$ and $0.32 u$, on the right side are $0.94 u$ and $0.25 u$. These movements are much higher than displacements along the $x$-axis of the maxilla in the intact skull. Since the cleft palate is on the left side of the skull, the displacements of the maxilla left side are higher than the displacements of the right side for the models $A$ and $B$ patterns of the transversal deformations (along the $x$-axis) for skull with models $A$ and $B$ are almost identical. At the same time, the magnitude of transversal displacements of the skull with model $A$ is on average at three times higher than the corresponding displacements for skull with model $B$. 
a)

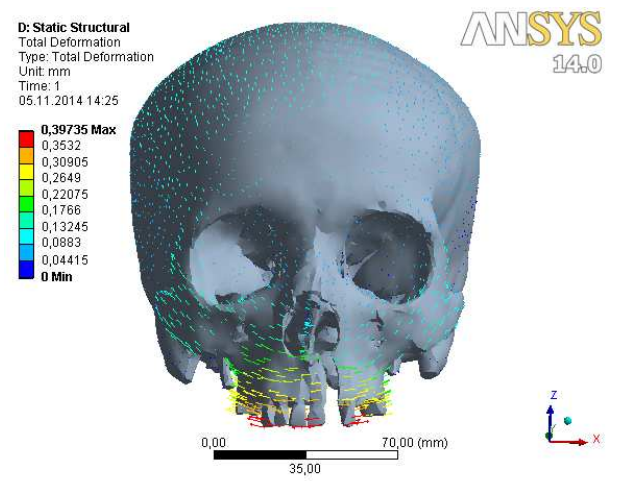

b)

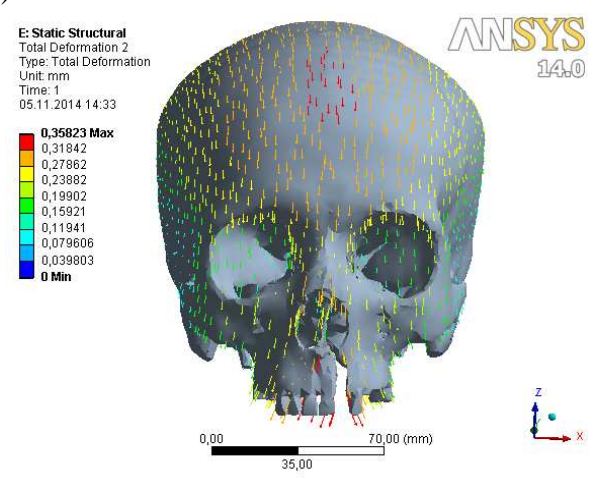

Fig. 4. Total deformations of skull with palate cleft (frontal view): a) model $A$, b) model $B$

Table 3. Maximum and minimum displacements of the bone structures for skull with palate cleft for models $A$ and $B$ of the orthodontic device

\begin{tabular}{|c|c|c|c|c|}
\hline \multirow{2}{*}{$\begin{array}{c}\text { Direction } \\
\text { of displace- } \\
\text { ments }\end{array}$} & \multicolumn{2}{|c|}{ Magnitude, $\mathbf{m m}$} & \multicolumn{2}{|c|}{ The skull bone structures } \\
\hline & $\begin{array}{c}\text { model } \\
A\end{array}$ & $\underset{B}{\operatorname{model}}$ & $\operatorname{model} A$ & model $B$ \\
\hline \multirow[t]{2}{*}{ Along $x$-axis } & 0.385 & 0.128 & \multirow[t]{2}{*}{ maxilla and zygomatic bone } & \multirow[t]{2}{*}{ maxilla } \\
\hline & -0.375 & -0.099 & & \\
\hline \multirow[t]{2}{*}{ Along $y$-axis } & 0.102 & 0.067 & frontal and temporal bones & maxilla \\
\hline & -0.074 & -0.312 & maxilla near palate cleft & frontal and parietal bones \\
\hline \multirow[t]{2}{*}{ Along $z$-axis } & 0.114 & 0.172 & $\begin{array}{l}\text { lateral part of maxilla and } \\
\text { zygomatic bone }\end{array}$ & occipital bone \\
\hline & -0.055 & -0.344 & $\begin{array}{l}\text { maxilla near palate cleft and } \\
\text { occipital bone }\end{array}$ & $\begin{array}{l}\text { posterior part of maxilla } \\
\text { and nasal bone }\end{array}$ \\
\hline
\end{tabular}

In the sagittal plane, there are both qualitative and quantitative differences between deformations of the maxillary complex. Displacements along $y$-axis for skull with model $A$ have positive values for the anterior incisors region. Displacements of parietal bone have negative values. For model $A$ almost the all maxilla moves slightly back and the parietal bone significantly leans forward. Zygomatic bones have the greatest displacements in the positive direction of the $z$-axis (up). Region of the maxilla moves slightly down in the vicinity of the cleft. For the model $B$ maxilla evenly moves down. The occipital bone is displaced up.

Deformations of the supporting teeth for the skull with a cleft palate (fig. 5.) shows that the dislocation of the supporting teeth is not observed for the models $A$ and $B$. The centers of rotation of the teeth almost coincide with the centers of rotation of the respective halves of the maxilla for models $A$ and $B$. 
a)

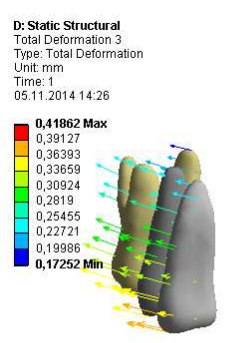

b)

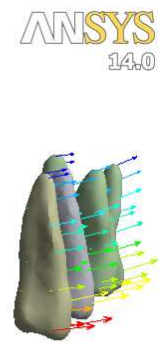

$\stackrel{z}{\longrightarrow} x$

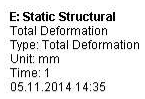

05.11.201414:35
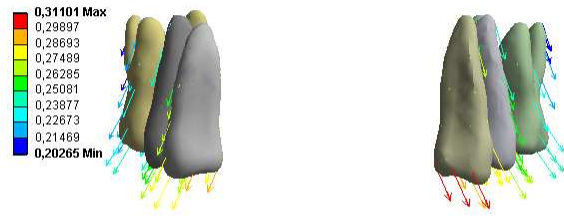

$\stackrel{z}{\longrightarrow}$

Fig. 5. Total deformations of the supporting teeth in the skull with palate cleft (frontal view): a) model $A$, b) model $B$

\section{Conclusions}

Finite element analysis of the maxillary expansion, based on the application of a load directly from the orthodontic device HYRAX, more accurately simulates the action of orthodontic forces and the behavior of the skull. Such approach allows explaining the clinically observed effects [4, 11, 13, 16, 20, 25].

Computations of the maxilla bone structures deformations showed that the design of orthodontic device HYRAX with the location of the screw in the same horizontal plane with rods and design with the location of the screws near palate are not optimal. In the first case there is substantial upward displacement of the side portions of the upper jaw, the upper jaw halves rotate with rotation center in the horizontal plane as well as a substantial rotational displacement the supporting teeth. The main advantage of the horizontal orthodontic design is significant transversal movement of the maxilla for the intact skull and for the skull with a cleft palate. Transversal deformations of the maxillofacial complex are significantly reduced, if the screw orthodontic appliance is located near the palate. At the same time, deformations of the maxillary complex and supporting teeth repeatedly increase in the sagittal plane, and cause the rotation of the cranium forwardly and downwardly in the plane.

The occurrence of undesirable displacements of the craniofacial complex in the sagittal plane indicates the need to predict the optimal location of the device screw relative to the palate. It also seems advisable resizing device plates to prevent rotation of the maxilla in a horizontal plane. Asymmetry of transversal displacements for the intact skull and skull with palate cleft indicates the importance of correct fixing rods device on the crown, both in height and circuit of the crown. 


\section{Acknowledgement}

The research leading to these results has received funding from the People Programme (Marie Curie International Research Staff Exchange) of the European Union's Seventh Framework Programme FP7/2007-2013/ under REA grant agreement No. PIRSES-GA-2013-610547.

\section{References}

[1] Boryor A., Geigera M., Hohmann A., Wunderlich A., Sander C., Sander F.M., Sander F.G.: Stress distribution and displacement analysis during an intermaxillary disjunction. A three-dimensional FEM study of a human skull, J. Biomechanics, 41 (2008), 376-382.

[2] Braun S., Bottrel J.A., Lee K.G., Lunazzi J.J., Legan H.L.: The biomechanics of maxillary sutural expansion, American J. Orthodontics Dentofacial Orthopedics, 118 (2000), 257-261.

[3] Chaconas S.J., Caputo A.A.: Observation of orthopedic force distribution produced by maxillary orthodontic appliances, American J. Orthodontics Dentofacial Orthopedics, 82 (1982), 492-501.

[4] Chung C.H., Font B.: Skeletal and dental changes in the sagittal, vertical, and transverse dimensions after rapid palatal expansion, American J. Orthodontics Dentofacial Orthopedics, 126 (2004), 569-575.

[5] Gautam P., Zhao L., Patel P.: Biomechanical response of the maxillofacial skeleton to transpalatal orthopedic force in a unilateral palatal cleft, Angle Orthodontist, 81 (2011), 503-509.

[6] Ghoneima A., Abdel-Fattah E., Hartsfield J., El-Bedwehi A., Kamel A., Kulaf K.: Effects of rapid maxillary expansion on the cranial and circummaxillary sutures, American J. Orthodontics Dentofacial Orthopedics, 140 (2011), 510-519.

[7] Han U.A., Kim Yo., Park J.U.: Three-dimensional finite element analysis of stress distribution and displacement of the maxilla following surgically assisted rapid maxillary expansion, J. Cranio-Maxillofacial Surgery, 37 (2009), 145-154.

[8] Holberg C., Holberg N., Schwenzer K., Wichelhaus A., Rudzki-Janson I.: Biomechanical analysis of maxillary expansion in CLP patients, Angle Orthodontist, 77 (2007), 280-287.

[9] Isaacson R.J., Ingram A.H.: Forces produced by rapid maxillary expansion. Part II. Forces present during treatment, Angle Orthodontist, 34 (1964), 261-270.

[10] Isaacson R.J., Wood J.L., Ingram A.H.: Forces produced by rapid maxillary expansion. Part I. Design of the force measuring system, Angle Orthodontist, 34 (1964), 256-260.

[11] Işeri H., Tekkaya A.E., Öztan Ö., Bilgiç S.: Biomechanical effects of rapid maxillary expansion on the craniofacial skeleton, studied by the finite element method, European J. Orthodontics, 20 (1998), 347-356.

[12] Jafari A., Shetty K.S., Kumar M.: Study of stress distribution and displacement of various craniofacial structures following application of transverse orthopedic forces - a three-dimensional FEM study, Angle Orthodontist, 73 (2003), 12-20. 
[13] Kragt G., Duterloo H.S., Ten Bosch J.J.: The initial reaction of a macerated human skull caused by orthodontic cervical traction determined by laser metrology, American J. Orthodontics Dentofacial Orthopedics, 81 (1982), 49-56.

[14] Landes C.A., Laudermann K., Petruchin O., Mack M.G., Kopp S., Ludwig B., Sader R.A., Seitz O.: Comparison of bipartite versus tripartite osteotomy for maxillary transversal expansion using 3-dimensional preoperative and postexpansion computed tomography data, J. Oral Maxillofacial Surgery, 67 (2009), 2287-2301.

[15] Lee H., Ting K., Nelson M., Sun N., Sung S.J.: Maxillary expansion in customized finite element method models, American J. Orthodontics Dentofacial Orthopedics, 136 (2009), 367-374.

[16] Ludwig B., Baumgaertel S., Zorkun B., Bonitz L., Glasl B., Wilmes B., Lisson J.: Application of a new viscoelastic finite element method model and analysis of miniscrew-supported hybrid hyrax treatment, American J. Orthodontics Dentofacial Orthopedics, 143 (2013), 426-435.

[17] Majourau A., Nanda R.: Biomechanical basis of vertical dimension control during rapid palatal expansion therapy, American J. Orthodontics Dentofacial Orthopedics, 106 (1994), 322-328.

[18] Memikoglu T.U.T., Işeri H.: Effects of a bonded rapid maxillary expansion appliance during orthodontic treatment, Angle Orthodontist, 69 (1999), 251-256.

[19] Pan X., Qian Y., Yu J., Wang D., Tang Y., Shen G.: Biomechanical effects of rapid palatal expansion on the craniofacial skeleton with cleft palate: a three-dimensional FE analysis, Cleft Palate-Craniofacial J., 44 (2007), 149-154.

[20] Provatidis C., Georgiopoulos B., Kotinas A., McDonald J. P.: On the FEM modeling of craniofacial changes during rapid maxillary expansion, Medical Engng. Physics, 29 (2007), 566-579.

[21] Sander C., Hüffmeier S., Sander F. M., Sander F. G.: Initial results regarding force exertion during rapid maxillary expansion in children, J. Orofacial Orthopedics, 67 (2006), 19-26.

[22] Susami T., Kuroda T., Amagasa T.: Orthodontic treatment of a cleft palate patient with surgically assisted rapid maxillary expansion, Cleft Palate-Craniofacial J., 33 (1996), 445-449.

[23] Tanne K., Sakuda M.: Biomechanical and clinical changes of the craniofacial complex from orthopedic maxillary protraction, Angle Orthodontist, 61 (1991), 145-152 .

[24] Timms D.J.: A study of basal movement with rapid maxillary expansion, American J. Orthodontics Dentofacial Orthopedics, 77 (1980), 500-507.

[25] Wang D., Cheng L., Wang C., Qian Y., Pan X.: Biomechanical analysis of rapid maxillary expansion in the UCLP patient, Medical Engineering and Physics, 31 (2009), 409-417.

[26] Weissheimer A., Macedo de Menezes L., Mezomo M., Dias D.M., Santayana de Lima E.M., Rizzatto S.M.D.: Immediate effects of rapid maxillary expansion with Haas-type and hyrax-type expanders: A randomized clinical trial, American J. Orthodontic Dentofacial Orthopedics, 140 (2011), 366-376. 
[27] Wood S.A., Strait D.S., Dumont E.R., Ross C.F., Grosse I.R.: The effects of modeling simplifications on craniofacial finite element models: The alveoli (tooth sockets) and periodontal ligaments, Journal of Biomechanics, 44 (2011), 1831-1838 .

[28] Zimring J.F., Isaacson R.J.: Forces produced by rapid maxillary expansion. Part III. Forces present during retention, Angle Orthodontist, 35 (1965), 178-186.

\section{WPLYW RODZAJU APARATU HYRAX NA ODKSZTAŁCENIA ZESPOŁU CZASZKOWO-TWARZOWEGO}

\section{Streszczenie}

Analizę stanu naprężeń oraz odkształceń ludzkiej czaszki po rozszczepie szczęki górnej za pomocą różnych aparatów ortodontycznych wykonano za pomocą metody elementów skończonych. Model numeryczny MES zespołu twarzowo-czaszkowego oraz zębów podporowych uzyskano na podstawie danych tomograficznych. Przyrządy ortodontyczne różnią się lokalizacją śruby względem podniebienia. Uwzględniano konstrukcję złożoną z prętów i śrub $\mathrm{w}$ tej samej płaszczyźnie poziomej oraz konstrukcję ze śrubą zlokalizowaną $8 \mathrm{~mm}$ bliżej podniebienia względem lokalizacji poziomej. Otrzymano odkształcenia w nienaruszonej czaszce oraz w czaszce z rozszczepieniem podniebienia. Miejsca największych odkształceń struktury kości czaszki zdefiniowano dla różnych projektów aparatów ortodontycznych. Analizowano wpływ konstrukcji aparatu ortodontycznego na przemieszczenia zębów podporowych. Wyniki mogą być wykorzystane w projektowaniu aparatów HYRAX do ortodontycznej korekcji i w leczeniu pacjentów ze zgryzem krzyżowym.

Słowa kluczowe: czaszka nienaruszona, rozszczep podniebienia, aparat HYRAX, stan naprężeniowo-odkształceniowy

DOI: $10.7862 / \mathrm{rm} .2015 .1$

Otrzymano/received: 10.12.2014 r.

Zaakceptowano/accepted: 12.03.2015 r. 